\title{
STRATEGI MEMBELAJARKAN MATEMATIKA PADA SISWA LAMBAN BELAJAR KELAS VIII INKLUSI DI SMP PGRI 1 SAMPIT
}

\author{
Nurul Hidayati Shaliha \\ Universitas Wiralodra, Jalan Ir. H. Juanda KM.3 Indramayu, nurulhs0624@ gmail.com
}

\begin{abstract}
ABSTRAK
Tujuan Penelitian ini adalah untuk mendiskripsikan strategi guru dalam membelajarkan matematika terkait dengan pengetahuan konseptual dan prosedural pada kelas VIII di SMP PGRI 1 Sampit. Penelitian ini merupakan penelitian kualitatif dengan metode penelitian studi kasus atau penelitian lapangan, yaitu mempelajari secara mendalam mengenai sistem pembelajaran di sekolah inklusi dan strategi membelajarkan matematika di kelas inklusi.Subjek penelitian ini adalah guru dan siswa lamban belajar kelas VIII SMP PGRI 1 Sampit. Data dalam penelitian ini berupa informasi tentang strategi guru dalam membelajarkan matematika di kelas VIII inklusi. Hasil penelitian ini adalah strategi membelajarkan matematika di kelas VIII inklusi SMP PGRI 1 Sampit dilihat dari keterampilan guru menjelaskan sesuai dengan indikator penyajian penjelasan yaitu adanya perencanaan penjelasan, kejelasan penyajian suatu penjelasan, pemberian tekanan dalam penjelasan, dan memberikan umpan balik kepada siswa. Untuk memudahkan guru dalam menanamkan konsep, guru menggunakan strategi pembelajaran yang berbasis kontekstual (contextual teaching and learning)dan untuk menanamkan konsep prosedural guru menggunakan metode discovery learning
\end{abstract}

Kata Kunci : Sistem Pembelajaran, Strategi Membelajarkan Matematika, Inklusi.

\begin{abstract}
The objectives of this research wereto describe teacher strategy in teaching mathematics from the teacher's ability in explaining in accordance with conceptual and procedural knowledge of 8th grade students of SMP PGRI 1 Sampit. This research is a qualitative descriptive using a single case study method, in depth study of learning system and mathematics learning in inclusive school.The subject of the research is mathematic teacher and slow learner student of the 8th grade from SMP PGRI 1 Sampit. The data of this research are information about the teacher strategy in learning Mathematics in the inclusive 8th grade.The research results showthe mathematics learning strategy in the inclusive 8th grade of SMP PGRI 1 Sampit observed from the teacher's ability in explaining the subject in accordance with the delivering explanation indicators which are planning the explanation, clarity of delivering the explanation, the use of examples and illustrations, the use of intonation in delivering the explanation, and giving the feed back to the students. The teacher used Contextual Teaching and Learning (CTL) to teach the concept of mathematics and Discovery Learning methods to teach the procedure of mathematics.
\end{abstract}

Keywords: Learning System, Mathematics Learning Strategy, Inclusive.

How to Cite: Shaliha, N. H. (2017). Strategi Membelajarakan Matematika pada Siswa Lamban Belajar Kelas VIII Inklusi di SMP PGRI 1 Sampit. Mathline: Jurnal Matematika dan Pendidikan Matematika, Vol 2, No.1, 71-80. 


\section{PENDAHULUAN}

Pendidikan merupakan dasar manusia untuk membangun kehidupannya. Melalui pendidikan, kualitas hidup seseorang menjadi berbeda satu dengan yang lainnya. Dalam Undang Undang Dasar 1945 pasal 31 ayat 1 dan Undang Undang Nomor 20 tahun 2003 tentang Sistem Pendidikan Nasional, disebutkan bahwa negara memberikan jaminan sepenuhnya kepada semua anak untuk memperoleh layanan pendidikan yang bermutu. Dalam pasal ini mencakup pendidikan bagi setiap individu yang menjadi warga negara Indonesia, baik individu normal maupun berkekurangan mendapat kesempatan yang sama untuk memperoleh pendidikan tanpa memandang latar belakang dan kondisi yang ada pada setiap individu tersebut. Memberikan kesempatan pendidikan yang sama pada hakikatnya berarti mengusahakan terciptanya suatu lingkungan di mana setiap anak mampu mengembangkan potensi yang dimilikinya secara optimal, artinya pendidikan yang diberikan harus sesuai dengan bakat dan kemampuan setiap anak. Akan tetapi sebagian dari mereka sering disebut juga sebagai exceptional students (siswa luar biasa) karena keterampilan dan kemampuan fisik, intelektual, atau perilakunya berbeda (Woolfolk, 2009).

Di sekolah reguler terdapat anak yang termasuk exceptional students, salah satunya yaitu anak yang mengalami kesulitan belajar. Istilah lain anak berkesulitan belajar sering kali diidentikkan dengan anak berkebutuhan khusus dengan kategori lamban belajar (slow learner) yang terlihat dari rendahnya prestasi belajar anak tersebut (Koswara, 2013). Menurut Scheerenberger, sebagian peneliti juga mengatakan bahwa batas siswa dikatakan slow learner, jika skor IQ berkisar antara 70 dan 85 (Shawet al, 2005). Oleh karena itu, meskipun slow learner mungkin memiliki kebutuhan pendidikan khusus, namun slow learner kurang cocok dengan sistem pendidikan khusus (MacMillanet al, 1998). Kemudian, pemerintah telah memberikan landasan hukum yang konkrit dan operasional tentang Penyelenggaraan Pendidikan Khusus untuk anak yang memiliki kesulitan dalam pembelajaran yang disebutkan dalam Undang-Undang Nomor 20 tahun 2003 tentang Sistem Pendidikan Nasional Pasal 32 ayat 1 yang berbunyi pendidikan khusus merupakan pendidikan bagi peserta didik yang memiliki tingkat kesulitan dalam mengikuti proses pembelajaran karena kelainan fisik, emosional, mental, sosial dan atau memiliki potensi kecerdasan dan bakat istimewa (Depdiknas, 2007). Sebagai bentuk pemerataan pendidikan maka pemerintah menggalakkan pendekatan pendidikan inklusi. Melalui pendidikan 
inklusi ini diharapkan sekolah-sekolah reguler dapat melayani semua anak, termasuk yang memiliki kebutuhan pendidikan khusus. Hal tersebut telah disebutkan melalui Keputusan Menteri Pendidikan dan Kebudayaan Nomor 002/U/1986 yang menyebutkan telah dirintis pengembangan sekolah penyelenggaraan pendidikan inklusi yang melayani penuntasan wajib belajar bagi peserta didik yang berkebutuhan khusus (Depdiknas, 2007).

Pendidikan inklusi harus bertujuan memfasilitasi peserta didik dengan kebutuhan khusus seperti slow learner agar dapat mengeksplorasikan dan mengembangkan kemampuan mereka secara maksimal, terutama dalam pelaksanaan proses pembelajaran. Pelaksanaan proses pembelajaran yang terjadi di kelas, yang berisi siswa inklusi dan siswa reguler haruslah memiliki strategi-strategi jitu dari seorang guru agar semua siswa memperoleh pengetahuan seperti yang kita inginkan. Sebagai seorang guru yang profesional harus mampu memenerapkan keterampilan-keterampilan dasar mengajarnya secara optimal sekalipun dengan kelas yang berbeda pada umumnya, terutama keterampilan dalam menjelaskan, di mana guru menyajikan materi secara lisan kepada siswa.

Kesulitan yang dialami siswa slow learner dalam matematika pada awalnya berkisar pada penguasaan empat operasi dasar yaitu penjumlahan, pengurangan, perkalian, dan pembagian (Kroesbergen\& Vanluit, 2003). Kemudian, berdasarkan penelitian yang dilakukan oleh Geary (2004) yang menyatakan bahwa terdapat 5\% sampai 8\% siswa sekolah dasar yang memiliki masalah dengan kemampuan kognitif mereka terkait dengan konsep atau prosedur di dalam matematika. Peneliti lain juga menemukan sekitar 5-6\% siswa mengalami kesulitan yang signifikan dalam matematika dan kebanyakan dari mereka tidak teridentifikasi sejak awal sebagai siswa yang memerlukan perhatian khusus dalam pelajaran matematika sampai sekolah menengah (McGlaughlinet al, 2005). Hal ini mengakibatkan jika tidak ditangani sejak awal kelemahan berhitung anak-anak sekolah dasar tersebut terutama dalam pengetahuan konseptual dan proseduralnya akan semakin membuat mereka mengalami kesulitan belajar matematika yang lebih tinggi lagi ditingkatan sekolah selanjutnya. Terutama bagi anak-anak yang memang memiliki kemampuan berpikir rendah.

Untuk mengetahui lebih lanjut mengenai kegiatan pembelajarannya seperti apa sistem dan strategi guru dalam mengajar matematika di sekolah inklusi maka peneliti melakukan observasi di sekolah inklusiyaitu SMP PGRI 1 Sampit yang memiliki sistem pembelajaran khusus untuk siswa inklusi yang berbeda dengan siswa reguler. Sekolah ini 
memiliki dua guru matematika, dalam setiap kelasnya. Siswa inklusi di sekolah ini berjumlah 28 orang dengan kategori siswa slow learner atau lamban belajar yaitu 5 orang yang terdapat pada kelas VIII. Kemudian berdasarkan informasi pengawas terkait mengatakan bahwa SMP ini sedang berkembang dengan model pendidikan inklusi yang berbeda.

Berdasarkan uraian yang dikemukakan tersebut, tujuan dari penelitian ini adalah untuk mendeskripsikan strategi guru dalam membelajarkan matematika terkait dengan keterampilan menjelaskan pengetahuan konseptual dan prosedural pada kelas VIII inklusi di SMP PGRI 1 Sampit.

\section{METODE PENELITIAN}

Penelitian ini dilaksanakan di SMP PGRI 1 Sampit khususnya pada kelas VIII inklusi. Penelitian ini menggunakan pendekatan kualitatif dengan metode penelitian studi kasus yaitu bagaimana strategi guru dalam membelajarkan matematika pada anak inklusi di kelas VIII SMP PGRI 1 Sampit. Subjek dalam penelitian ini guru matematika pendamping khusus dan siswa lamban belajar di kelas VIII. Teknik pengambilan subjek penelitian ini adalah purposive sampling.

Data yang dikumpulkan melalui penelitian ini adalah data yang sesuai dengan fokus penelitian, yaitu mengenai cara guru matematika pendamping khusus siswa inklusi kelas VIII SMP PGRI 1 sampit dalam membelajarkan matematika pada siswa inklusi khususnya yang lamban belajar terkait dengan keterampilan menjelaskan konsep dan prosedur yaitu peristiwa atau aktivitas yang berupa kegiatan proses pembelajaran guru matematika pendamping khusus kelas VIII yang bertindak sebagai pelaku yang menjadi objek pengamatan dalam penelitian ini dan sebagai responden yang menjawab daftar pertanyaan peneliti.

Sesuai dengan bentuk pendekatan penelitian kualitatif dan sumber data yang akan digunakan maka teknik pengumpulan data dalam penelitian ini adalah observasi, wawancara mendalam dan dokumentasi. Data mengenai strategi guru matematika pendamping khusus kelas VIII dalam membelajarkan matematika di kelas melalui observasi dan wawancara. Peneliti melakukan observasi pasif dengan alat bantu perekam, untuk mengamati perilaku yang muncul di lokasi penelitian tetapi peneliti hanya sebagai pengamat pasif. Digunakan teknik member check untuk mengetahui seberapa jauh data yang diperoleh sesuai dengan apa yang diberikan informan serta dilanjutkan dengan 
wawancara mendalam.

Validitas data yang digunakan dalam penelitian ini adalah: 1) perpanjangan keikutsertaan, 2) ketekunan/ keajegan pengamatan, 3) member check untuk analisis data strategi guru dalam membelajarkan matematika kepada siswa inklusi. Member check ini dilakukan dengan tujuan agar informasi yang diperoleh dan akan digunakan dalam penulisan laporan sesuai dengan apa yang dimaksud oleh informan. Untuk itu peneliti melakukan konfirmasi dengan guru yang bersangkutan mengenai hasil analisis di lapangan, dan apabila data yang ditemukan peneliti disepakati oleh guru berarti data tersebut valid. Apabila guru yang bersangkutan tidak sepakat dengan hasil yang ditemukan peneliti, maka dilakukan diskusi dengan guru untuk menyesuaikan dengan informasi yang diberikan oleh guru mengenai kegiatan membelajarkan matematika untuk anak inklusi.

Setelah data diperoleh dan terkumpul dilakukan tahapan selanjutnya yaitu teknik analisis data dengan metode analisis data kualitatif yang mengikuti konsep Miles dan Huberman yaitu reduksi data, penyajian data, dan penarikan kesimpulan (Moleong, 2012). Langkah yang dilakukan dalam analisis data untuk sistem pembelajaran inklusi di SMP PGRI 1 Sampit yaitu diperoleh dengan metode dokumentasi dan pengamatan langsung. Selanjutnya dari pengamatan dan dokumentasi tersebut peneliti jadikan bahan untuk wawancara subjek. Hasil wawancara dari subjek tersebut berupa rekaman suara subjek dalam mengungkapkan sistem pembelajaran inklusi yang akan ditranskrip secara teliti. Kemudian menganalisis hasil transkrip dan catatan lapangan dengan metode Miles dan Huberman.Langkah yang dilakukan dalam analisis data untuk strategi guru dalam membelajarkan matematika yaitu diperoleh melalui hasil observasi yang berupa rekaman kegiatan pembelajaran matematika yang akan ditranskrip secara teliti dan rinci dari awal hingga akhir kegiatan pembelajaran. Dengan demikian akan diperoleh transkrip berupa kumpulan percakapan guru dan siswa. Setelah hasil rekaman ditranskrip secara lengkap, maka langkah selanjutnya yaitu menganalisis hasil transkrip dan catatan lapangan dengan langkah-langkah metode Miles dan Huberman.

\section{HASIL PENELITIAN DAN PEMBAHASAN}

Strategi guru dalam membelajarkan matematika yang akan dibahas adalah kemampuan menjelaskan guru pembimbing khusus dalam membelajarkan matematika terkait dengan pengetahuan konseptual dan prosedural. Berdasarkan observasi dan wawancara yang dilakukan oleh peneliti pada guru pendamping khusus matematika kelas 
VIII SMP PGRI 1 Sampit, strategi yang digunakan guru selama proses pembelajaran pada materi persamaan garis lurus serta materi persamaan linier dua variabel dimulai dari perencanaan penjelasan pada observasi pertama adalah guru membuat LKS pengenalan persamaan gari lurus serta mempersiapkan materi dengan menganalisa pembelajaran sampai dengan menggambar persamaan garis lurus pada bidang kartesius dan guru mengaitkan setiap penjelasan dengan rumus yang akan digunakan. Sedangkan pada observasi keempat, guru terlebih dahulu mempersiapkan siswa sebelum memulai pembelajaran dengan membagi soal dan meminta siswa membaca soal tersebut.

Dari kedua observasi tersebut, dapat dilihat bahwa strategi guru hampir sama dengan perencanaan penjelasan pada umumnya. Guru telah menyertakan dengan jelas apa yang hendak dijelaskan dengan menampilkan masalah melalui lembar kerja siswa yang dibuat khusus oleh guru. Guru juga memperhatikan keadaan kelas dan kemampuan siswa. perbedaan terlihat dari materi dan soal yang dibuat guru. Soal untuk anak inklusi sangat sederhana dan jelas untuk setiap langkahnya. Selain itu, guru juga telah siap dengan menjelaskan kembali perhitungan dasar seperti pengurangan, pembagian dan perkalian. Guru memberikan perhatian intensif dan selalu membentuk kelompok menjadi satu bersama siswa inklusi. Pembelajaran berlangsung face to face. Selain itu dengan pemberian tugas melalui LKS, menurut Triani \& Amir (2013) merupakan salah satu metode yang efektif sebagai salah satu metode belajar bagi anak lamban belajar untuk meningkatkan kemampuan siswa dalam pengetahuan prosedural. Lebih banyak memberikan latihan akan membuat siswa menjadi lebih banyak mengingat.

Kemudian penyajian materi, untuk kejelasan penyajian penjelasan pada observasi pertama strategi yang dilakukan guru yaitu guru memulai penjelasan dengan menggambar Sedangkan pada observasi keempat, guru memulai penjelasan dengan mengingatkan kembali konsep persamaan linier satu variabel, guru menggunakan kata-kata yang sederhana dan detail, dan guru langsung menunjuk pada soal ketika menjelaskan bagaimana cara mengerjakan soal tersebut. Strategi guru terlihat bahwa tidak hanya metode ceramah yang dilakukan tapi juga guru melakukan tindakan-tindakan langsung saat menjelaskan. guru mengatakan bahwa dengan penjelasan yang sangat rinci dan jelas itu akan sangat memudahkan siswa lamban belajar untuk memahami konsep maupun prosedurnya. Karena akan sangat sulit buat siswa jika tidak memahami, dengan karakteristik siswa lamban belajar yang sering lupa, siswa tidak mungkin menghapal 
materi ataupun rumus. Sehingga cara satu-satunya dengan membuat siswa paham, meskipun dengan waktu yang lebih lama.

Strategi yang diterapkan guru dalam penggunaan contoh dan ilustrasi pada penjelasan terlihat mulai dari observasi pertama yaitu guru melakukan pembelajaran konstektual dengan menjadikanbenda benda di lingkup sekolah sebagai contoh. Pada observasi keempat guru lebih banyak mengilustrasikan soal dan langsung memberikan contoh dengan mengerjakan salah satu soal yang diberikan. Guru menerapkan pembelajaran Contextual Teaching and Learning yang bertujuan membantu siswa memahami makna bahan pelajaran yang sedang dipelajari dengan cara menghubungkannya dengan konteks kehidupan siswa. Siswa menjadi lebih mudah menangkap konsep yang ingin disampaikan guru. Hal ini selaras dengan hasil penelitian yang dilakukan oleh Utami (2014) dengan objek penelitian siswa tunagrahita yang memiliki kemampuan lebih rendah dari siswa lamban belajar bahwa dengan penggunaan media konkrit dan tidak menyajikan pembelajaran yang ikonik dan simbolik akan lebih efektif untuk menanamkan pengetahuan konseptual.

Strategi yang dilakukan guru dalam penyajian penjelasan dengaan kategori pemberian tekanan ,terutama siswa yang lamban belajar berulang-ulang dengan penuh kesabaran dan senyuman, guru memberikan penekanan lewat jalur bahasa, dan guru memotivasi siswa dengan kata-kata. Kemudian pada observasi keempat, guru memberikan penekanan pada suara yang lebih bervariasi disesuaikan dengan apa yang akan disampaikan. Baik itu penekanan suara menjadi tegas, lembut, dan bernada rendah, guru memusatkan perhatian siswa inklusi melalui ekspresi keterkejutan untuk memancing perhatian siswa tersebut, dan guru memberikan perintah mengerjakan soal dengan ekspresi lembut dan disertai senyuman kepada siswa inklusi. Permainan nada suara dan ekspresi efektif meningkatkan ketertarikan siswa terhadap pembelajaran yang berlangsung.

Selain itu, strategi yang dilakukan guru melalui penekanan penjelasan yang dilakukan dengan berulangkali menjelaskan konsep yang sama kepada siswa lamban belajar dilakukan karena kemampuan mengingat siswa tersebut yang rendah. Penjelasan berulang tentang materi yang diajarkan atau remedial teaching sangat efektif. Hal ini berdasarkan penelitian Selvarajan \& Vasanthagumar (2012) terhadap siswa lamban belajar di kota Mannar, Srilanka yang hasilnya menyebutkan bahwa dengan remedial teaching akan memperbaiki kemampuan pencapaian pemahaman siswa menjadi lebih baik. 
Strategi yang dilakukan guru saat memberikan umpan balik pada observasi pertama yaitu guru memberikan pertanyaan-pertanyaan kepada siswa lamban belajar, lebih banyak dari pada siswa inklusi lain dan guru menjawab dengan antusias balikan dari siswa untuk memastikan jawabannya benar atau tidak. untuk melihat sampai sejauh mana siswa mendengarkan penjelasan dan mampu memahami apa yang dijelaskan. Guru juga melihat apakah siswa fokus atau tidak, jadi dengan memberikan siswa pertanyaan balik juga sebagai cara untuk mengajak siswa kembali fokus saat mereka mulai bosan atau jenuh. Pembelajaran seringkali membosankan dan jenuh, hal ini dikarenakan penjelasan yang berulang-ulang dan keputusasaan siswa saat kesulitan memahami.

Pada observasi keempat yang dilakukan guru yaitu guru memberikan kesempatan kepada siswa inklusi untuk menunjukkan pemahaman atau keraguannya selagi penjelasan berlangsung dan guru mengembalikan pertanyaan yang ditanyakan oleh siswa, untuk memancing siswa menemukan jawabannya sendiri.

Strategi yang dilakukan guru untuk membelajarkan pengetahuan prosedural dapat terlihat dari sikap guru yang banyak memberikan pertanyaan dan mengembalikan pertanyaan dari siswa kembali ke siswa untuk menemukan jawabannya sendiri atau bisa juga disebut dengan Discovery Learning. Menurut Triani\& Amir (2013) Discovery Learning merupakan salah satu metode pengajaran untuk anak lamban belajar yang bertujuan mendorong anak untuk mencari tahu jawaban yang benar atau salah dengan usahanya sendiri. Siswa mampu menemukan jawaban asalkan materi yang diberikan lebih sederhana.

Dari keseluruhan strategi yang dilakukan guru untuk membantu siswa lamban belajar memahami penjelasan yang diberikan dapat ditarik kesimpulan. Strategi untuk membelajarkan pengetahuan konseptual guru menggunakan pembelajaran kontekstual. Sedangkan untuk membelajarkan pengetahuan prosedural guru menggunakan metode discovery learning. Dilihat dari tipe keterampilan menjelaskannya guru termasuk dalam tipe II yaitu penggunaan generalisasi dalam menjelaskan sesuai dengan maksud dan fungsinya. Diukur dari kemampuan menjelaskan, strategi yang dilakukan guru sudah sesuai dengan indikator penyajian penjelasan, yaitu perencanaan penjelasan, kejelasan penyajian suatu penjelasan, pemberian tekanan dalam penjelasan, dan pemberian umpan balik kepada siswa. Strategi ini cukup membantu siswa dalam memahami materi pelajaran yang disampaikan guru. Selain itu juga, guru melakukan remedial teaching, dan penggunaan waktu yang lebih lama dalam memberikan penjelasan. Ini dilakukan untuk 
mengatasi sifat pelupa dan kemampuan otak yang rendah dari siswa lamban belajar dalam menerima pengetahuan baru. Untuk itu, bisa dikatakan, strategi membelajarkan matematika dilihat dari kemampuan guru menjelaskan sudah sesuai dengan kemampuan memahami siswa lamban belajar.

\section{KESIMPULAN}

Berdasarkan hasil penelitian dan pembahasan diperoleh kesimpulan, strategi membelajarkan matematika di kelas VIII Inklusi di SMP PGRI 1 Sampit dilihat dari keterampilan guru menjelaskan, strategi yang dilakukan guru yaitu dalam perencanaan penjelasan guru telah menyertakan dengan jelas apa yang hendak dijelaskan dengan menampilkan masalah melalui lembear kerja siswa, merangkum materi yang akan diajarkan, memperhatikan keadaan kelas dan kemampuan siswa. Kemudian ketika menjelaskan, guru menggunakan bahasa yang sederhana dan jelas saat menyampaikan konsep bangun datar, guru memberikan contoh langsung dengan benda-benda yang ada di sekitar siswa, guru memberikan pertanyaan-pertanyaan kepada siswa lamban belajar untuk membuat mereka tetap fokus pada pelajaran, guru memberikan umpan balik ketika siswa bertanya, guru berulangkali menjelaskan saat siswa lupa tentang materi bangun datar persegi dan persegi panjang yang dijelaskan, guru menggunakan bahasa sehari-hari siswa dan menggunakan intonasi suara yang bervariasi saat menjelaskan, dan guru membimbing siswa tahap demi tahap dalam proses mengerjakan soal yang diberikan. Selain itu juga, guru melakukan remedial teaching, dan penggunaan waktu yang lebih lama dalam memberikan penjelasan, ini dilakukan untuk mengatasi sifat pelupa dan kemampuan otak yang rendah dari siswa lamban belajar dalam menerima pengetahuan baru. Untuk itu, bisa dikatakan, strategi membelajarkan matematika dilihat dari kemampuan guru menjelaskan sudah sesuai dengan kemampuan memahami siswa lamban belajar.

Berdasarkan kesimpulan hasil penelitian maka peneliti mengemukakan beberapa saran yaitu bagi sekolah diharapkan dapat memperbaiki sistem pembelajaran inklusi, terutama untuk pelaksanaan Program Pembelajaran Individual (PPI), sesuai dengan pedoman penyelenggaraan program inklusi yang ditetapkan oleh pemerintah. Bagi guru reguler, diharap dapat memperbaiki proses membelajarkan matematika di kelas inklusi yang terkait dengan hal-hal sebagai berikut: 
a. kegiatan membelajarkan matematika untuk siswa inklusi seharusnya tetap dilakukan oleh guru reguler yaitu guru kelas atau guru mata pelajaran, dengan materi khusus yang sudah dimodifikasi

b. tugas - tugas yang dilakukan guru pendamping khusus yang saat ini dilakukan dikelas mulai dari menanamkan konsep maupun prosedur sampai dengan pembuatan bahan ajar dan LKS khusus siswa inklusi seharusnya dilakukan oleh gurur kelas dan guru mata pelajaran.

c. pada pelaksanaan kegiatan membelajarkan hendaknya guru mulai mengembangkan penyajian penjelasan dengan menggunakan teknologi informasi dan komunikasi. Penggunaan media pembelajaran seperti penyampaian dengan tampilan slide atau power point akan membuat siswa menjadi lebih bergairah dan bersemangat serta menghilangkan kejenuhan siswa dengan materi matematika yang sulit mereka pahami.

Bagi guru pendamping khusus, seharusnya melakukan tugas seperti yang telah ditetapkan saat diangkat menjadi guru pendamping khusus siswa inklusi. Seharusnya guru pendamping khusus hanya memonitor bagaimana perkembangan pendidikan siswa inklusi. Bukan menjadi guru utama bagi siswa inklusi tersebut.

\section{DAFTAR PUSTAKA}

Depdiknas. (2007). Pedoman Khusus Penyelenggaraan Pendidikan Inklusi: Identifikasi Anak Berkebutuhan Khusus. Jakarta: Direktorat Jenderal Manajemen Pendidikan Dasar dan Menengah.

Geary, C. D. (2004). Mathematics and Learning Disability. Journal of Learning Disabilities, vol. 1, no. 37, hlm. 4 - 15 .

Koswara, D. (2013). Pendidikan Anak Berkebutuhan Khusus berkesulitan Belajar Spesifik. Jakarta: PT. Luxima Metro Media.

Kroesbergen, E.H. \& VanLuit, J. E. H. (2003). Mathematics Intervention for Children With Special Education Needs (A Meta-Analysis). Remedial and Special Education, vol. 24, no. 2, hlm. 97-114.

MacMillan, D.L., Gresham, F.M., Bocian, K.M., \& Lambros, K. (1998). Current Plight of Borderline Students: Where Do They Belong?. Education and Training in Mental Retardation \& Developmental Disabilities, vol. 33, hlm. 83-94.

McGlaughlin, S.M., Knoop, A.J., \& Holiday, A.G., (2005). Differentiating Students With Mathematics Difficulty in College: Mathematics Disabilities Vs. No Diagnosis. Learning Disabilities Quarterly, vol. 28, hlm. 223-232.

Moleong, L. J. (2012). Metodologi Penelitian Kualitatif. Bandung: Remaja Rosdakarya.

Selvarajan, P. \& Vasanthagumar, T. (2012). The Impact of Remedial Teaching on Improving The Competencies of Low Achievers. International Journal of Social Science \& Interdisciplinary Research, vol. 1, no. 9, hlm. 49 - 58.

Shaw, S., Grimes, D., \& Bulman, J. (2005). Educating Slow Learners: Are Charter Schools 
the Last, Best, Hope for Their Educational Success?. The Charter Schools Resource Journal, vol. 1, no. 1, hlm. 10-11.

Triani, N. \& Amir. (2013). Pendidikan Anak Berkebutuhan Khusus Lamban Belajar (Slow Learner). Jakarta: PT. Luxima Metro Media.

Utami, A. D. (2014). Strategi Guru dalam Membelajarkan Matematika pada Materi Lingkaran kepada Anak Tunagrahita (Studi Kasus pada Siswa Kelas VIII SD Muhammadiyah Cерu). Tesis pada Universitas Sebelas Maret Surakarta: Tidak diterbitkan.

Woolfolk, A. (2009). Educational Psychology Active Learning. Yogyakarta: Pustaka Pelajar. 